IRA-International Journal of Management \& Social Sciences

ISSN 2455-2267; Vol.07, Issue 03 (2017)

Pg. no. 423-437

Institute of Research Advances

http://research-advances.org/index.php/RAJMSS

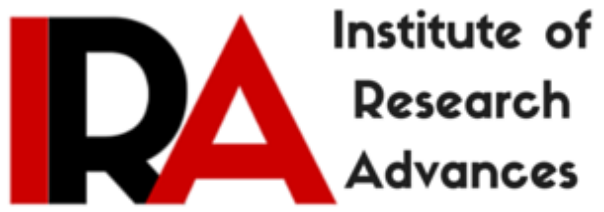

\title{
Effect of Work Attitude and Total Productive Maintenance on the Overall Equipment Effectiveness and Production Continuity
}

\author{
Puadi Haming ${ }^{1}$, Mahfud Nurnajamuddin ${ }^{2}$, Hamzah Hafied ${ }^{3}$, Serlin Serang ${ }^{4}$ \\ ${ }^{1}$ Doctoral Student in the Faculty of Economics, Muslim University of Indonesia, \\ Indonesia. \\ ${ }^{2,3,4}$ Faculty of Economics, Muslim University of Indonesia, Indonesia.
}

Type of Review: Peer Reviewed.

DOI: http://dx.doi.org/10.21013/jmss.v7.n3.p3

\section{How to cite this paper:}

Haming, P., Nurnajamuddin, M., Hafied, H., \& Serang, S. (2017). Effect of Work Attitude and Total Productive Maintenance on the Overall Equipment Effectiveness and Production Continuity. IRA-International Journal of Management \& Social Sciences (ISSN 2455-2267), 7(3), 423-437. doi:http://dx.doi.org/10.21013/jmss.v7.n3.p3

(C) Institute of Research Advances

\section{(cc) EY-NC}

This work is licensed under a Creative Commons Attribution-Non Commercial 4.0 International License subject to proper citation to the publication source of the work.

Disclaimer: The scholarly papers as reviewed and published by the Institute of Research Advances (IRA) are the views and opinions of their respective authors and are not the views or opinions of the IRA. The IRA disclaims of any harm or loss caused due to the published content to any party. 


\begin{abstract}
This study aims to examine and analyze the impact of work attitude, Total Productive Maintenance (TPM) on the Overall Equipment Effectiveness (OEE) and production continuity and the other effect of Work Attitude and Total Productive Maintenance (TPM) on production continuity: The mediating role of Overall Equipment Effectiveness (OEE). The research was conducted at PT. Semen Tonasa i.e. units II to $V$ unit which is the largest cement producer in eastern Indonesia. Withdrawal of respondents did with the criteria that only respondents yang having their respective sectors and who have work experience of at least one year were used as samples. Results of analysis Partial Least Square (PLS) Version 2.0.M3 used in analyzing the contribution of exogenous variables on endogenous variables directly, Sobel Test was used for pushing analyze the contribution of the indirect effect (mediation) whereas importanceperformance analysis (IPA) to analogous interpret the relationship loading factor value and the average value. The results of this study provide evidence of work attitude has a positive and significant effect on the overall equipment effectiveness (OEE), total productive maintenance (TPM) has a positive and significant effect on overall equipment effectiveness (OEE), work attitude, total productive maintenance $(T P M)$ and overall equipment effectiveness (OEE) positive and significant impact on production continuity.
\end{abstract}

Keywords: Work Attitude, Total Productive Maintenance, Overall Equipment Effectiveness, production continuity

\title{
Introduction
}

Currently in Indonesia has entered a new era in trade which ASEAN community free trade era marked by the implementation of the ASEAN Economic Community (AEC) in 2015 on January 1, 2016 which aims to improve competitiveness and promote economic growth in Indonesia. These conditions have an impact on increasing competition among businesses, particularly in manufacturing companies. To maintain a presence of the company in the competitive arena that is increasingly competitive, companies must have a competitive advantage that is realized with superior quality, cost advantages, advantages in speed surrender and flexibility (Aquilano et al., 1995; Wijngaard, \& Karaesmen 2007; Welker \& Wijngaard, 2009; Krajewski et al., 2005; Heizer \& Render, 2004; Haming \& Nurnajamuddin, 2012). Continuous quality improvement in Japanese terminology is called Kaizen or Quality Management is done by considering the integration of cost and quality so as to improve the efficiency of a gradual and continuous, and at the same time the company can make quality improvements are then expected to approach the expectations of consumers so that at a certain point the company can produce the output quality with price compete.

Improvement of manufacturing systems is one of intense effort and should be done; for it takes the support of the performance of the equipment should be in maintenance well to obtain optimal results in order to ensure product quality and sustainability of production. 5S Initially based on the Japanese Acronyms of Seiri (organization), Seiton (neatness), Seiso (cleaning), Seiketsu (Standardization) and Shitsuke (discipline), is used as a platform for developing an integrated management system by the parallel use of total productive maintenance (TPM) (Bamber et al., 2000). Indonesian context has called the method 5R (Sort, Straighten, Shine, Standardize, Sustain) is the process of creating and maintaining neatness, cleanliness and high performance in the workplace in an organized manner that serves as the foundation for continuous improvement, $5 \mathrm{~S}$ is a good starting point for the overall improvement of the company's program (Koufteros et al., 1998; Osada, 1989; 1991). Total Productive Maintenance (TPM) is a fundamental program for the development of the maintenance function within an organization, which involves the entire organization's Resources (Nakajima, 1988). Total Productive Maintenance (TPM) 
intend to increase the significantly production value and at the same time increasing employee morale and job satisfaction (Venkatesh, 2007).

The existence of Total Productive Maintenance (TPM) makes maintenance has an important function in the business world. The effectiveness of the maintenance function significantly contributes to the performance of equipment, production and product (Teresko, 1992; Wakjira \& Ajit Pal, 2012). Total Productive Maintenance (TPM) enables companies to have production equipment maintenance program so that the production process can run effectively and efficiently. Operation of the company efficiently and effectively be done by ensuring that there are no interruptions in production caused by damage, discharge and engine failure (Mad Lazim \& Ramayah 2010; Hapsari et al., 2012; Baru et al., 2013) that the method used as Gauges in the application of Total Productive Maintenance (TPM), which one is the Overall Equipment Effectiveness (OEE), measurement indicators developed by Seiichi Nakajima (1988) is useful to evaluate and demonstrate the effectiveness of manufacturing operations equipment.

Overall Equipment Effectiveness (OEE) is used as a measurement of the performance of the system maintenance, using this method it is known the availability of equipment, production efficiency, and quality output of equipment (Borris, 2006). Empirical evidence suggests that there are significant 5R working attitude to Overall Equipment Effectiveness (OEE) and there is influence significant work attitude 5R with manufacturing productivity, then there is the influence of Overall Equipment Effectiveness (OEE) the productivity of manufacturing (Sahu et al., 2015). Six Big Losses (TPM) practice has a positive effect on the value of Overall Equipment Effectiveness (OEE) (Suhendra \& Betrianis, 2006). In Simultaneously all variables six big losses (TPM) significantly affect on Overall Equipment Effectiveness (OEE), but set up and defect did not significantly affect on the Overall Equipment Effectiveness (OEE) (Sari \& Sutopo, 2008). The impact of the increased cost of energy, industrial pollution, shortage of raw materials and natural resources, as well as an ecological disaster resulting in the importance of setting production continuity indicator adopted of sustainable development (economic, environmental and social) (Molamohamadi \& Ismail, 2014). The high level of global cement consumption resulted in significant pollution levels become; there is a skeptical outlook and growing among consumers about the validity of the "green". Sustainability is a very complex issue, the increased importance of issues related to sustainability and environmental management programs to ensure the implementation of the concept of environmentally friendly (Shrivastava et al., 2014). The importance of measuring the sustainability of cement production based on indicators of economic, environmental and social (Amrina \& Vilsi, 2015).

PT. Semen Tonasa the cement industry is the largest in eastern Indonesia, the company is required to maintain continuity of production, produce a quality product, competitive and able to satisfy consumers, these conditions can be done by reducing the level of damage to the machine(breakdown) which is often the case with arranging back system maintenance(maintenance) of the overall equipment and facilities owned, then the company is also required to maintain the continuity of the production of environmental and social aspects. Based on empirical facts on the ground and review the research problem was identified in this study, that is the attitude of work and Total Productive Maintenance (TPM) effect on Overall Equipment Effectiveness (OEE) and production continuity (KP)?

\section{METHODS}

This research approach uses explanatory research that aims to clarify the effect of exogenous variables on endogenous variables and interpretation of research data in support with descriptive statistical analysis. The study was conducted at PT. Semen Tonasa in Pangkajene district, the execution time of the research was conducted in September 2016 - January 2017. Data were collected through questionnaires and field observation. Criteria used to determine the respondents, namely; (1) The employees have the task fields associated with the variables studied, (2) the employee know the variables in the analysis, and the employee has a work experience of at least 1 (one) year in their respective sectors. The populations in this study were employees working at PT. Semen Tonasa Unit Unit II to V. The samples were taken by 
purposive sampling. Data was analyzed by using PLS (Partial Least Square), the equation analysis based Structural Equation Model variants that can simultaneously testing the measurement model (outer model) and structural models (inner model) and to analyze the indirect effects used Sobel Test.

\section{Results}

\section{Statistical Analysis Descriptive Variables}

Respondents in this study has an employee who understand clearly about their respective sectors associated with the variables studied, is concerned to understand the variables studied and have work experience of at least 1 year in the production department of each unit (unit II, until the unit V). Work attitude variable measured by $5 \mathrm{~S}$ (Sort, Straighten, Shine, Standardize, Sustain) shows the average value of 74.37, which means that respondents has understand of $5 \mathrm{R}$ importance in finding a way to implement its work well, easy, efficient and convenient. The perception averages of respondents for each indicator are: the indicator sort, with a mean of 70.98, and then to the indicator Straighten, showed an average yield of 73.34, then in shine indicator) with an average of 74.47, and Standardize has the mean value of 76.32 and sustain with a mean of 76,72 .

Total Productive Maintenance (TPM) is measured through six (6) indicator, the indicator prevents damage to machinery / equipment with a mean of 77.34, then to suppress indicator adjustment time machine with a mean of 76.05 , next to the indicator to prevent bottlenecks in production process with a mean value of 76.19 as well as on indicators of preventing decrease operating speeds with a mean of 76.86 , then the indicator preventing the defect with a mean value of 76.71 and the last to prevent a decline in the results obtained indicators mean value of 80,18 .

Responder on variable overall equipment effectiveness (OEE) with the average value of the respondents amounted to 71.05 , on the other portion indicators Overall equipment effectiveness (OEE) used in this study, the availability to the value - average of respondents was 69, 32, and Performance Efficiency 68,38 , then the latter Quality Rate with value - average responder at 75.45. Responder on other variables namely is production continuity at 79.77. The most important indicator is shown on environmental indicators at 81.29 , then for economic indicators with an average value of 79.02 , then social indicators with a value of 79.01 .

\section{Model analysis}

\section{a) Outer Model}

Evaluation includes three stages: an evaluation of convergent validity, discriminant validity and reliability of composite. 
Figure 1. Results of PLS Algorithm (Early Model)

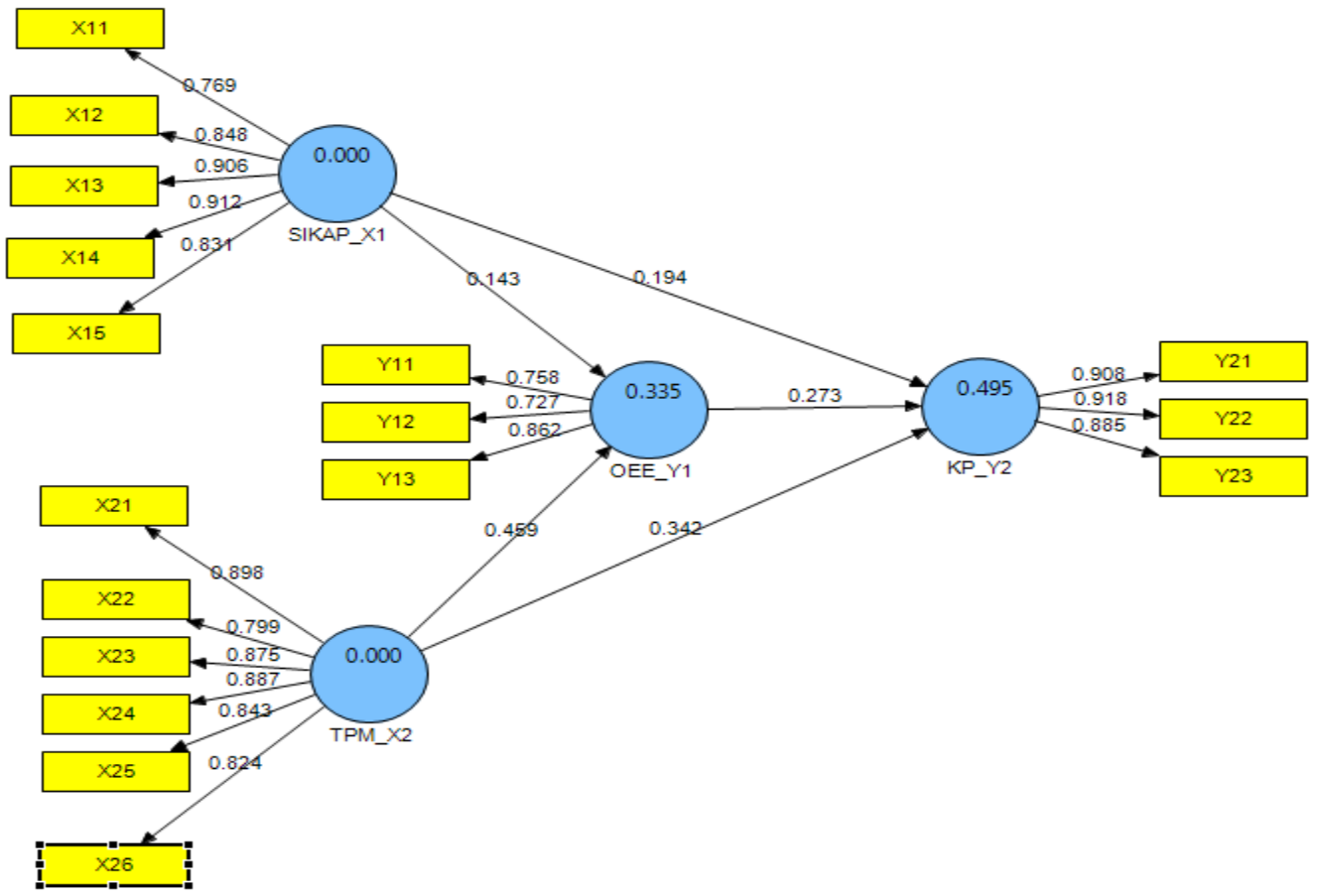

Source: Data processing SmartPLS (2017)

\section{b) Convergent validity test}

Table 1. Outer Loadings (Mean, STDEV, T-Values)

\begin{tabular}{|c|c|c|c|c|c|c|}
\hline \multirow{2}{*}{ Variable } & \multirow{2}{*}{ Indicators } & \multicolumn{2}{|c|}{$\begin{array}{l}\text { Original sample } \\
\text { estimate }\end{array}$} & \multirow{2}{*}{$\begin{array}{c}\text { Mean of } \\
\text { subsamples }\end{array}$} & \multirow{2}{*}{$\begin{array}{l}\text { Standard } \\
\text { deviation }\end{array}$} & \multirow{2}{*}{ t-statistic } \\
\hline & & $\begin{array}{l}\text { Indicators } \\
\text { value }\end{array}$ & mean & & & \\
\hline \multirow{5}{*}{ Work attitude } & $\mathrm{X}_{1.1}$ & 0,769 & \multirow{5}{*}{0,853} & 0,768 & 0,029 & 26,292 \\
\hline & $\mathrm{X}_{1.2}$ & 0,848 & & 0,848 & 0,015 & 57,670 \\
\hline & $\mathrm{X}_{1.3}$ & 0,906 & & 0,906 & 0,009 & 99,621 \\
\hline & $\mathrm{X}_{1.4}$ & 0,912 & & 0,913 & 0,008 & 118,671 \\
\hline & $\mathrm{X}_{1.5}$ & 0,831 & & 0,832 & 0,016 & 51,869 \\
\hline \multirow{6}{*}{$\begin{array}{c}\text { Total Productive } \\
\text { Maintenance (TPM) }\end{array}$} & $\mathrm{X}_{2.1}$ & 0,898 & \multirow{6}{*}{0,854} & 0,898 & 0,009 & 1,053 \\
\hline & $\mathrm{X}_{2.2}$ & 0,799 & & 0,799 & 0,020 & 399,929 \\
\hline & $\mathrm{X}_{2.3}$ & 0,875 & & 0,875 & 0,013 & 681,930 \\
\hline & $\mathrm{X}_{2.4}$ & 0,887 & & 0,889 & 0,009 & 989,075 \\
\hline & $\mathrm{X}_{2.5}$ & 0,843 & & 0,839 & 0,023 & 359,418 \\
\hline & $\mathrm{X}_{2.6}$ & 0,824 & & 0,825 & 0,012 & 695,446 \\
\hline \multirow{3}{*}{$\begin{array}{l}\text { overall equipment } \\
\text { effectiveness (OEE) }\end{array}$} & $\mathrm{Y}_{1.1}$ & 0,824 & \multirow{3}{*}{0,782} & 0,753 & 0,033 & 231,195 \\
\hline & $Y_{1.2}$ & 0,727 & & 0,722 & 0,039 & 186,361 \\
\hline & $Y_{1.3}$ & 0,862 & & 0,863 & 0,015 & 579,589 \\
\hline \multirow{3}{*}{$\begin{array}{l}\text { production } \\
\text { continuity }\end{array}$} & $\mathrm{Y}_{2.1}$ & 0,908 & \multirow{3}{*}{0,904} & 0,908 & 0,009 & 1,020 \\
\hline & $Y_{2.2}$ & 0,918 & & 0,919 & 0,009 & 1,051 \\
\hline & $Y_{2.3}$ & 0,885 & & 0,885 & 0,011 & 790,916 \\
\hline
\end{tabular}

Source: Data processing SmartPLS (2017) 
Convergent validity is used to test whether the indicators used capable of accurately measuring latent constructs (Garson, 2002; in Suriyanti, 2012). Convergent validity test occurs if the score obtained from two different instruments that measure the same construct has a high correlation (Hartono, 2008; in Willy Abdillah, 2015). Rule of thumb used to measure the convergent validity was outer loading, and using the parameters Variance Extracted (AVE) average, and Communality. A construct is expressed strongly correlated when the value of the loading factor > 0.7, AVE > 0.5, and Communality >0.5 (Imam Ghozali and Hengky Latan, 2015; 76). Loading factor is the correlation between the indicators of the variables, the higher the loading factor to makes the better the indicator in measuring the variables. Table 1 show that all indicators of the variables (the original field sample estimate) have a loading factor $>0.70$. Work attitude with loading factor an average 0, 8531, TPM with loading factor an average 0, 8544, OEE with loading factor an average 0,7823 and Production continuity (PC) with loading factor an average 0,9039 .

\section{c) Discriminant validity test}

How to test the discriminant validity with reflective indicator is to look at the value of cross loading for each variable must be> 0.70 and comparing the square root of AVE for each construct with the correlation between the constructs in the model. The validity of the discriminant which is well demonstrated on the square root of AVE for each construct is greater than the correlation between the constructs in the model (Fornell \& Larcker, 1981; in Imam Ghozali \& Hengky Latan, 2015,)

Table 2. Cross Loading

\begin{tabular}{|c|c|c|c|c|c|}
\hline Variable & Indicator & $\begin{array}{c}\text { Work } \\
\text { attitude }\left(\mathrm{X}_{1}\right)\end{array}$ & $\mathrm{TPM}\left(\mathrm{X}_{2}\right)$ & $\operatorname{OEE}\left(\mathrm{Y}_{1}\right)$ & $\mathrm{PC}\left(\mathrm{Y}_{2}\right)$ \\
\hline \multirow{5}{*}{ Work attitude } & $\mathrm{X}_{1.1}$ & 0,769 & 0,483 & 0,234 & 0,438 \\
\hline & $\mathrm{X}_{1.2}$ & 0,848 & 0,670 & 0,315 & 0,462 \\
\hline & $\mathrm{X}_{1.3}$ & 0,906 & 0,711 & 0,527 & 0,533 \\
\hline & $\mathrm{X}_{1.4}$ & 0,912 & 0,754 & 0,451 & 0,503 \\
\hline & $\mathrm{X}_{1.5}$ & 0,831 & 0,722 & 0,541 & 0,604 \\
\hline \multirow{6}{*}{ TPM } & $\mathrm{X}_{2.1}$ & 0,761 & 0,898 & 0,430 & 0,622 \\
\hline & $X_{2.2}$ & 0,638 & 0,799 & 0,422 & 0,471 \\
\hline & $\mathrm{X}_{2.3}$ & 0,733 & 0,875 & 0,503 & 0,609 \\
\hline & $\mathrm{X}_{2.4}$ & 0,636 & 0,887 & 0,397 & 0,522 \\
\hline & $\mathrm{X}_{2.5}$ & 0,667 & 0,843 & 0,578 & 0,477 \\
\hline & $\mathrm{X}_{2.6}$ & 0,628 & 0,824 & 0,573 & 0,614 \\
\hline \multirow{3}{*}{ OEE } & $\mathrm{Y}_{1.1}$ & 0,232 & 0,286 & 0,824 & 0,337 \\
\hline & $Y_{1.2}$ & 0,313 & 0,269 & 0,727 & 0,273 \\
\hline & $Y_{1.3}$ & 0,539 & 0,635 & 0,862 & 0,599 \\
\hline \multirow{3}{*}{$\mathrm{PC}$} & $\mathrm{Y}_{2.1}$ & 0,531 & 0,585 & 0,512 & 0,908 \\
\hline & $Y_{2.2}$ & 0,546 & 0,632 & 0,591 & 0,918 \\
\hline & $\mathrm{Y}_{2.3}$ & 0,565 & 0,547 & 0,422 & 0,885 \\
\hline
\end{tabular}

Source: Data processing SmartPLS (2017)

The validity test results discriminant with the value of cross loading on Table 2, indicating that cross loading with items measuring larger than other constructs, then this indicates that the latent constructs predict the size of the block they are better than the other block size so that it can be interpreted, that meets the criteria of validity discriminant. Another test to assess the validity of discriminant is to look at the value AVE and the square root of AVE constructs as depicted in the following table. 
Table 3. Average variance extracted and correlation between latent variables

\begin{tabular}{|l|c|c|c|c|c|c|}
\hline \multirow{2}{*}{ Variable } & Composite & \multirow{2}{*}{ AVE } & \multicolumn{4}{|c|}{ Correlation Matrix } \\
\cline { 4 - 7 } & Reliability & & Work attitude & TPM & OEE & PC \\
\hline Work attitude & 0,731 & 0,855 & 1 & & & \\
\hline TPM & 0,731 & 0,855 & 0,794 & 1 & & \\
\hline OEE & 0,615 & 0,785 & 0,507 & 0,572 & 1 & \\
\hline PC & 0,817 & 0,904 & 0,604 & 0,652 & 0,567 & 1 \\
\hline
\end{tabular}

Source: Data processing SmartPLS (2017)

Based on Table 3 shows that each variable has a value of AVE $>0.50$ indicating the ability of the latent variables in explaining or representing the original variable values meet predetermined criteria. Other criteria can be seen by comparing the square root of AVE, the correlation between latent variables show that the AVE square root of each latent variable is greater than the correlation with other latent variables. Work Attitude of $0,85470>$ of correlation with other latent variables, i.e. TPM by 0,794, with OEE of 0,507 and with PC of 0,604 . TPM has amounted to $0.855>$ of correlation with other latent variables are work attitude of 0,794 , with OEE of 0,572 and with PC by 0,652 . OEE has amounted to $0.785>$ of correlation with other latent variables are work attitude of $0,0,507$, with TPM of 0,572 and PC of 0.567. PC has amounted to $0,904>$ of correlation with other latent variables are work attitude of 0.604027 , with TPM of 0,652170 and for OEE of 0,567. Thus, it can be concluded that all the latent variables have good discriminant validity.

\section{d) Reliability test}

Reliability tests performed to measure the internal consistency of measurement tools. Reliability indicates the accuracy, consistency and accuracy of a measuring instrument in measuring (Hartono, 2008; in Willy \& Jogiyanto, 2015: 196). Reliability test can use two methods: Cronbach's alpha and composite reliability. Cronbach's alpha measure the lower limit value of the reliability of a construct, while the composite reliability measure the true value of the reliability of a construct (Chin, 1995), but the composite reliability rated better in estimating the internal consistency of a construct (Salisbury, Chin, Gopal \& Newsted, 2002; in Willy \& Jogiyanto, 2015: 196)

Table.4 Cronbach Alpha and Composite Reliability

\begin{tabular}{|l|c|c|}
\hline \multicolumn{1}{|c|}{ Variable } & Cronbach's Alpha & Composite reliability \\
\hline Work attitude & 0,908 & 0,931 \\
\hline TPM & 0,926 & 0,942 \\
\hline OEE & 0,726 & 0,827 \\
\hline PC & 0,888 & 0,931 \\
\hline
\end{tabular}

Source: Data processing SmartPLS (2017)

Table 4. was obtained that the test results Composite Reliability Cronbach Alpha and each variabel > 0.70 so otherwise reliable. Thus, that variable Work Attitude, TPM, OEE and PC have good reliability.

\section{e) Inner model}

Structural model (inner model) is a structural model to predict the causal relationships between latent variables. Structural models were evaluated using the R-square for dependent constructs, the StoneGeisser Q-square test for predictive relevance and t-test statistics obtained through bootstrapping procedures as well as the significance of the coefficient parameters of structural lines. Q-square value $>0$ (zero) indicates that the model has predictive value relevance; while the Q-square value $<0$ indicates that the model lacks predictive relevance (Gozhali, 2014: 41). 
Figure 2. Results of PLS Algorithm (Final Model)

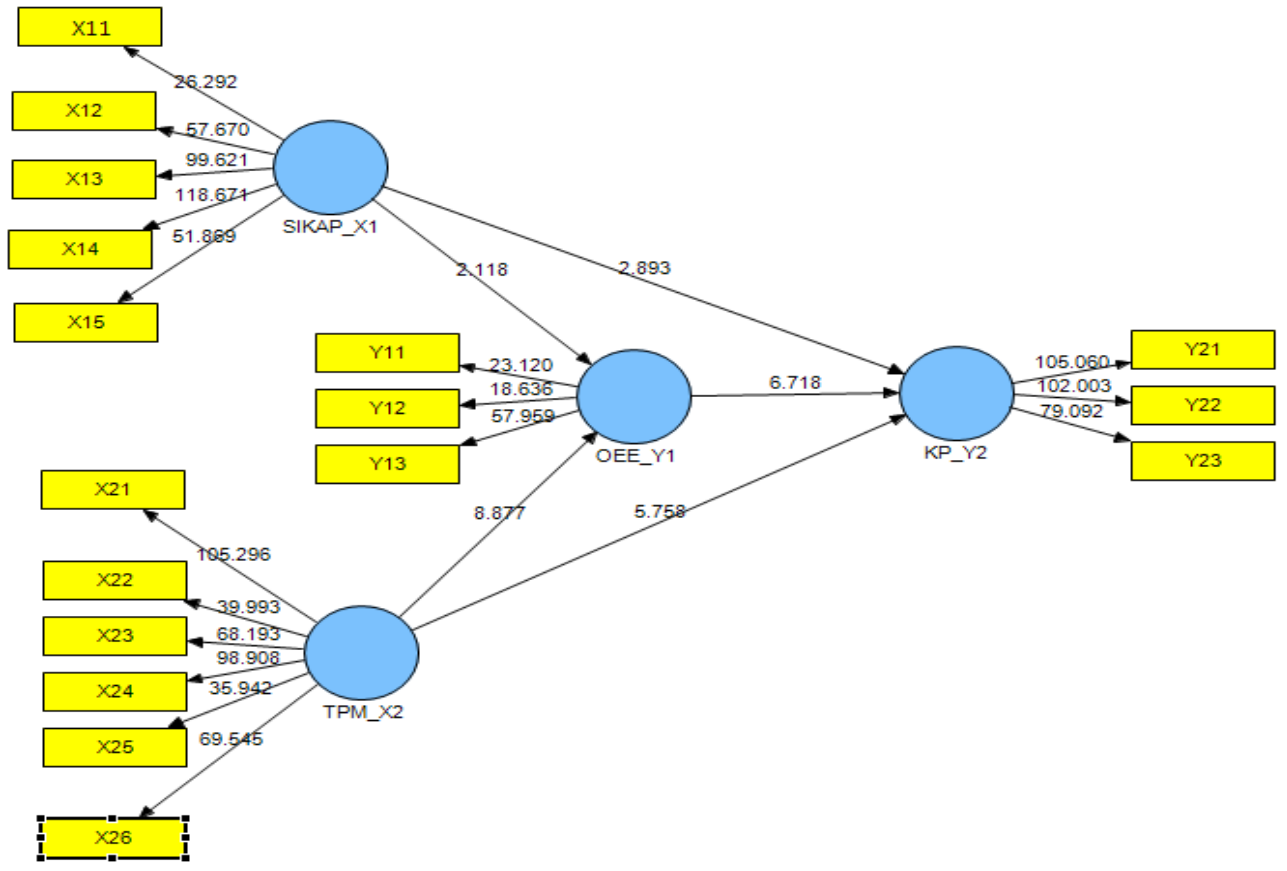

Source: Data processing SmartPLS (2017)

\section{f) Goodness of Fit test}

This test is intended to determine how much the result of a data model that explains variations (score) the original variable. Tests conducted by Stone-Geisser Q Square Test. Inner models explaining that there are two latent variables endogenous namely OEE and PC in order to obtain two coefficient of determination.

Table.5 R-square

\begin{tabular}{|c|c|c|c|}
\hline Equation & independent variable & dependent variable of & R-square \\
\hline 1 & Work Attitude & OEE & 0.340 \\
\hline 2 & TPM & PC & 0.500 \\
\hline
\end{tabular}

Source: Data processing SmartPLS (2017)

Based coefficient of determination value of each dependent variable $\mathrm{Q}^{2}$ with the formula:

$$
\mathrm{Q}^{2}=1-\left(1-\mathrm{R}_{1}{ }^{2}\right)\left(1-\mathrm{R}_{2}{ }^{2}\right)\left(1-\mathrm{R}_{3}{ }^{2}\right)\left(1-\mathrm{R}_{4}{ }^{2}\right)
$$

Description:

$\mathrm{R}_{1}^{2}=$ coefficient of determination for OEE

$\mathrm{R}_{2}{ }^{2}=$ coefficient of determination for PC

$\mathrm{Q}^{2}=1-\{(1-0,34)(1-0,50)\}$

$\mathrm{Q}^{2}=1-0.33$

$\mathrm{Q}^{2}=0.67$ or $67 \%$

Result of $\mathrm{R}^{2}$ obtained by the $0,335>0.33$ and $0,495>0,33$ indicates that the model is moderate (Chin, 1998, in Imam Ghozali \& Hengky Latan, 2015) and the results of $Q^{2}=0.67>0$ gives evidence that the model has predictive relevance (Gozhali, 2014: 42). Thus, the model deserves to be interpreted. 


\section{g) Relationship between variables}

To conclude whether the independent variable has a positive and significant effect on the dependent variable, use the cut-off value calculated value $=1.96$ (Gozhali.2015). Thus, if the value of t-statistic tested path coefficient of 1.96, then the exogenous variables have a significant effect on endogenous variables.

Table 6. Hypothesis Testing Results

\begin{tabular}{|l|c|c|c|c|c|}
\hline \multicolumn{1}{|c|}{ Path coefficient } & $\begin{array}{c}\text { Original } \\
\text { sample } \\
\text { estimate }\end{array}$ & $\begin{array}{c}\text { Mean of } \\
\text { subsamples }\end{array}$ & $\begin{array}{c}\text { Standard } \\
\text { deviation }\end{array}$ & t- statistic & Finding \\
\hline Direct effect & 0,143 & 0,144 & 0,067 & 2,118 & Significant \\
\hline Attitude -> OEE & 0,459 & 0,460 & 0,052 & 8,877 & Significant \\
\hline TPM -> OEE & 0,194 & 0,187 & 0,067 & 2,893 & Significant \\
\hline Attitude -> PC & 0,342 & 0,351 & 0,059 & 5,758 & Significant \\
\hline TPM -> PC & 0,273 & 0,271 & 0,041 & 6,718 & Significant \\
\hline OEE -> PC & \multicolumn{5}{|l}{} \\
\hline Indirect effect & 0,039 & 2,032 & Significant \\
\hline Attitude =>OEE=>PC & 0,125 & 5,316 & Significant \\
\hline TPM=>OEE=>KS &
\end{tabular}

Source: Data processing SmartPLS \& the Sobel test (2017)

Hypothesis testing results in Table 6 can be described according to the equation in the model as follows:

1) Work Attitude positive and significant impact on the Overall Equipment Effectiveness (OEE).Based on the results obtained by analysis of the value of t-statistic of $2,118>1.96$, it was concluded that the $\mathrm{H}_{1}$ is accepted, Thus, if the company has adopted the 5S work properly, it will increase the value of OEE

2) Total Productive Maintenance (TPM) positive and significant effect on the Overall Equipment Effectiveness (OEE). Based on the results obtained by analysis of the value of t-statistic of 8.887 $>1.96$, then concluded that $\mathrm{H}_{2}$ is accepted. Thus, where the application of TPM in the company increases, it will increase the value of OEE

3) Work attitude has a positive and significant impact on Production continuity. Based on the results obtained by analysis of the value of t-statistic of $2,893>1.96$, it was concluded that $\mathrm{H}_{3}$ is accepted. Thus, if the implementation of $5 \mathrm{~S}$ with good working attitude, it will boost the company's production continuity.

4) Total Productive Maintenance (TPM) positive and significant impact on the Production continuity. Based on the analysis, the value of t-statistic of 5,758 >1.96, it was concluded that $\mathrm{H}_{4}$ is accepted. Thus, where the application of TPM in the company increases, it will boost the company's production continuity.

5) Overall Equipment Effectiveness (OEE) positive and significant impact on the Production continuity. Based on the analysis, the value of t-statistic of $6.718>1.96$, it was concluded that the $\mathrm{H}_{5}$ is accepted. Thus, if the value of OEE increases, it will boost the company's production continuity.

6) Work attitude has a positive and significant impact on Production continuity as mediated the Overall Equipment Effectiveness (OEE). Based on the analysis, the value of t-statistic of 2.036 > 1.96, it was concluded that $\mathrm{H}_{6}$ is accepted. Thus, if the value of OEE increases as the impact of the increase results from the implementation of $5 \mathrm{~S}$ working attitude, it will boost the company's production continuity. 
7) Total Productive Maintenance (TPM) positive and significant impacts on Production continuity as a mediated the Overall Equipment Effectiveness (OEE). Based on the analysis, the value of tstatistic of $5.316>1.96$, it was concluded that $\mathrm{H}_{7}$ is accepted. Thus, if the value of OEE increases as the impact of the increase results from the application of TPM, it will boost the company's production continuity

\section{h) Interpretation of relations loading factor with the average value}

Interpretation of the relationship between the loading factor with a average value is done with the approach of interpretation in importance- performance analysis (IPA), the IPA is conducted to map the relationship between importance (relationship) and performance (satisfaction or performance) (Mulin \& Betsy, 1987; in Arif Kamar Bafadal, 2012) and the analogy is used to interpret the relationship loading factor with a value the mean average (Arif Kamar Bafadal, 2012)

Table 7. Loading factor and average value

\begin{tabular}{|c|c|c|c|c|c|}
\hline Measurement & $\begin{array}{c}\text { Loading } \\
\text { Factor }\end{array}$ & Mean & Measurement & $\begin{array}{c}\text { Loading } \\
\text { Factor }\end{array}$ & Mean \\
\hline $\mathrm{X}_{1.1}$ & 0,769 & 70,98 & $\mathrm{X}_{2.5}$ & 0,843 & 76,71 \\
\hline $\mathrm{X}_{1.2}$ & 0,848 & 73,34 & $\mathrm{X}_{2.6}$ & 0,824 & 80,18 \\
\hline $\mathrm{X}_{1.3}$ & 0,906 & 74,47 & $\mathrm{Y}_{1.1}$ & 0,758 & 69,32 \\
\hline $\mathrm{X}_{1.4}$ & 0,912 & 76,32 & $\mathrm{Y}_{1.2}$ & 0,727 & 68,38 \\
\hline $\mathrm{X}_{1.5}$ & 0,831 & 76,72 & $\mathrm{Y}_{1.3}$ & 0,862 & 75,45 \\
\hline $\mathrm{X}_{2.1}$ & 0,898 & 77,34 & $\mathrm{Y}_{2.1}$ & 0,908 & 79,02 \\
\hline $\mathrm{X}_{2.2}$ & 0,799 & 76,05 & $\mathrm{Y}_{2.2}$ & 0,918 & 81,29 \\
\hline $\mathrm{X}_{2.3}$ & 0,875 & 76,19 & $\mathrm{Y}_{2.3}$ & 0,885 & 79,01 \\
\hline $\mathrm{X}_{2.4}$ & 0,887 & 76,86 & & & \\
\hline
\end{tabular}

Source: Data processing SmartPLS (2017)

Figure 3. Quadrant average score (mean) and loading factor

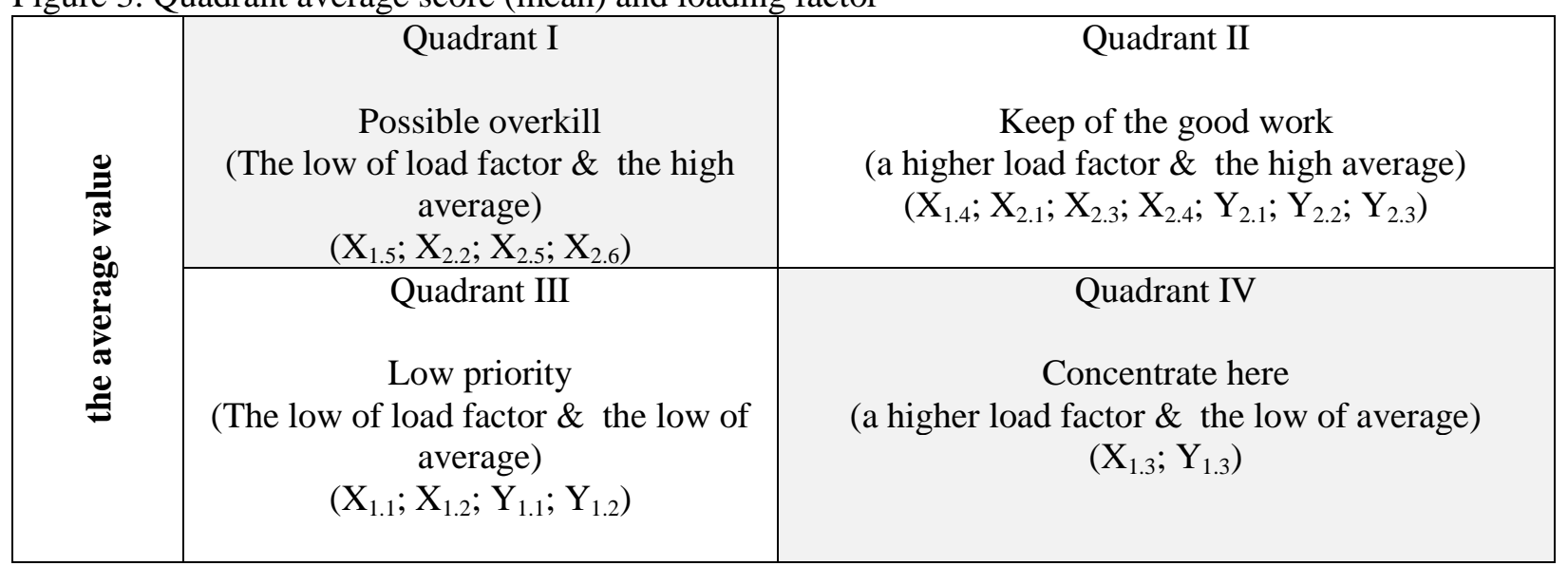

Source: Implementation from Arif Kamar Bafedal, (2012), Data Processing (2017)

1) Quadrant I, position gives a condition High Loading factor (the main indicator) can be interpreted that the results of observations of these indicators are very varied (uneven) so that the indicator may explain the variables strongly, whereas the mean value of average height can be interpreted, that the indicator the main has been rated as good by respondents with a status largely keep up the good work so as ought to be maintained by the company. The indicators that are in this position are: 1) indicator Standardize of work attitude, 2) indicators prevent damage to the equipment 
,preventing bottlenecks in the process ,preventing a decrease in speed of TPM, and 3) economic indicators, Environment, and social of production continuity

2) Quadrant II, Position gives a condition loading factor is low (Not the main indicator) illustrates that the contribution of indicators to explain the variables are weaker (not the main indicator) and the mean value of the average high that this indicator has been rated well by largely respondents so that the indicator which has been rated as good. If these indicators will be improved, it would be redundant or possible overkill, more appropriate to explain about the things what has been done so it can be applied to both companies. The indicators that are in this position are: 1) indicator Diligent of the work attitude, 2) indicators of time tuning adjustments to the machine prevent defects in the process and prevent the decrease in yield of TPM

3) Quadrant III, in this position describes the condition of loading factor a low with a mean value of the average low with status. Low priority. The indicators that are in this position are: 1) indicator sort and Straighten ,in the work attitude, 2) indicator availability , and Performance in the OEE

4) Quadrant IV, On position this describes the condition loading factor is high (the main indicator) with a mean average is low, it can be interpreted that the main indicator of variables still rated lower by partially respondents compared with other indicators that can be top priority, or concentrate here, need new effort better to be carried out so that the average could be a better indicator. The indicators that are in this position are: 1) Indicators shine in the work attitude, and 2) indicators quality in the OEE

\section{Conclusions and Recommendations}

Based on the analysis and the previous discussion, it can be summed up as follows; (1) 5R As a representations work attitude positive and significant impact on OEE; (2) TPM positive and significant impact on OEE; (3) 5R As a representations work attitude positive and significant effect on production continuity; (4) TPM has a positive and significant impact on production continuity; (5) OEE positive and significant impact on production continuity; (6) 5R As a representations work attitude positive and significant impact on production continuity as a mediated OEE; (7) TPM positive and significant impact on production continuity As a mediated OEE; (8) PT. Semen Tonasa has implemented a 5R with good working attitude, TPM properly so as to produce a good OEE and simultaneously a good working attitude, TPM was good with a good OEE can have a positive impact on the production of the company's sustainability.

This research raises some recommendations: (1) to obtain optimal results, it is hoped that PT. Semen Tonasa to concentrate on handling the straighten indicator (cleaning the work area and environment) of the $5 \mathrm{R}$ as a representations work attitude. Also concentrate on improving the implementation of quality indicators of OEE is more concentrated on efforts to increase production quality implementation without disabilities so that the average value of the indicator variable will be higher; (2) In addition, it is expected that the company retains the efforts that have been done on indicators of hospitalization of Work Attitude, indicator to prevent damage to equipment, preventing bottlenecks in the production process and prevent a decrease in the operating speed of the variable TPM, economic indicators, the environment and social sustainability of the variable production to be easily applied in the company; (3) The Company PT. Semen Tonasa need to further improve the implementation of the work attitude 5R though statistically, have a positive impact on OEE and production continuity with forming each work unit 5R organization with a clear structure with adequate supervision and continuous training. If possible outcome $5 \mathrm{R}$ can be competed every day so the company and give rewards to the group that assessed achievement apply $5 \mathrm{R}$ allowing groups that performed poorly motivated to implement $5 \mathrm{~S}$ better at his workplace in the future. 


\section{References}

1. Abdillah Willy \& Jogiyanto. (2015), Partial Least Squarctural (PLS) Alternative Structural Equation Medeling (SEM) In Business Research, Andi Offset, Yogyakarta

2. Afefy H. Islam. (2013). Productive Maintenance and Overall Equipment Effectiveness Evaluation. International Journal of Mechanical \& Mechatronics Engineering IJMME-IJENS Vol:13 No:01

3. Ahmad, Iwan Soenandi \& Christine Aprilla. (2013). Improved Performance of Machine With Measurement of OEE Value At Forging Department In PT. AAP. Journal of Scientific Industrial Engineering, Vol.1 No.2, 67-74

4. Almeanazel, Taisir Osama R. (2010). Total Productive Maintenance Review and Overall Equipment Effectiveness Measurement, Jordan Journal of Mechanical and Industrial Engineering Volume 4, Number 4, 517-522

5. Al-Rasyid, Harun. (1994). Sampling Technique and Preparation of Scale: Padjadjaran University. Bandung

6. Amrina Elita, \& Annike Lutfia Vilsi. (2015). Key Performance Indicators for Sustainable Manufacturing Evaluation in Cement Industry, $12^{\text {th }}$ Global Conference on Sustainable Manufacturing, Available online at www.sciencedirect.com, Procedia CIRP 26. 19-23

7. Aquilano, N. J., Chase, R. B., \& Davis, M. M. (1995). Fundamentals of operations management. Irwin Professional Publishing.

8. Bafadal Arif Kamar. (2012). Interpretation of the loading Factor value Relationship of the Measurement Model and the Average Value May 26, 2012

9. Bamber, C.J., Sharp, J.M. and Hides, M.T. (2000), "Developing management systems towards integrated manufacturing: a case study perspective", Integrated Manufacturing Systems, Vol. 11 No. 7, 454-61

10. Betrianis, Robby Suhendra. (2005). Measurement of Overall Equipment Effectiveness Value as Basic Business Process Improvement Manufacture On Production Line, Department of Industrial Engineering Vol.7, No.2, $91-100$

11. Boban Binoy, \& Joseph Jenson E. (2013), Enhancing Overall Equipment Effectiveness for a Manufacturing Firm through Total Productive Maintenance, International Journal of Emerging Technology and Advanced Engineering Volume 3, Issue 8, 425-429

12. Boris Steven. (2006). Total Productive Maintenance, McGraw-Hill, New York

13. David J Smith. (1973). Maintainability Engineering, Pitman Publishing

14. Dogra Manu, (2011). TPM-A Key Strategy for Productive Improvement in Process Industry, Journal of Engineering Science and Technology Vol. 6 No. 1 (2011): 1-16.

15. Edwards Sally, (2009). A New Way of Thinking: The Lowell Center Framework for Sustainable Products. University Of Massachusetts Lowell

16. Elmo J. Miller, Jerome W. Blood. (1971), Modern Maintenance Management, the America Management Association

17. Erni Nofi, \& Maulana Andri Fajar. (2012). Measurement of Production Machine Performance With Overall Equipment Effectiveness Method at PT. Cahaya Biru Sakti Abadi, Inovation Journal Volume 8, Number 2 80, 80 - 91

18. Fitria Sari Yuni \& Wahyudi Sutopo, (2008). OEE Size System Design To Monitor and Fix Process Efficiency in Filling and Packing Section. Performance (2008) Vol. 7. No. 1: 31 - 38

19. Gaspersz Vincent (2011). Oganizational Excellence, Systematic Continuos Improvement and Innovation, Vinchristo Publication, Bogor 16710

20. Ghozali Imam, \& Latan Hengky. (2015), Partial Least Squares Concepts, Techniques and Applications Using SmartPLS 3.0 Program, Diponegoro University, Semarang

21. Ghozali Imam. (2014). Structural Equation Modeling Alternative Method with Partial Least Squares (PLS), Diponegoro University, Semarang

22. Grag HP. (1976). Industrial Maintenance, Chand \& Company Ltd New Delhi 
23. Gupta Amit Kumar \& Garg. (2012). OEE Improvement by TPM Implementation: A Case Study, International Journal of IT, Engineering and Applied Sciences Research (IJIEASR) Volume 1, No. 1 October, 115-124

24. Haizer Jay \& Render Barry. (2011), Operation Management, Salemba Empat, Jakarta

25. Haming Murdifin \& Nurnadjamuddin Mahfud. (2012), Modern Production Management, Book 2, Paragonatama Jaya, Jakarta

26. Hapsari Nindita, Kifayah Amar \& Yandra Rahadian Perdana. (2012). Measurement of Machine Effectivity Using Overall Equipment Effectiveness (OEE) Method at PT. Setiaji Mandiri, Journal of Spectrum Industry, Vol. 10, No. 2 108-199

27. Ishikawa Kaoru, (1982). Guide To Quality Control, Tokyo: Asean Productivity Organization

28. Kartikasari Heni, Ismaini Zain \& Kartika Nuswantara. (2014). Multivariate Regression Analysis against Assessment of Listening, Structure, and Reading on EFL Test Scores of ITS Students, Journal of Science and Art Pomits Vol. 3, No.2,

29. Kathleen E. Mc Kone, (1999). Total Productive Maintenance: A Contextual View. Elsevier, Journal of Operation Management 17; 123-144

30. Katkamwar Sarang, Sadashiv Wadatkar \& Ravikant, (2013). Study of Total Productive Maintenance and It's Implementing Approach in Spinning Industries. International Journal of Engineering and Technology (IJETT) - Volume 4, Issues 5 - May 2013

31. Kenneth E.Rizzo, (1999). Total Productive Maintenance a Primer, Package Printing and Converting, 26

32. Koufteros, X. A., Vonderembse, M. A., \& Doll, W. J. (1998). Developing measures of time-based manufacturing. Journal of Operations management, 16(1), 21-41.

33. Lawrence D. Fredendal, J Wayne Patterson \& Willian J. Kennedy, (1997). Maintenance: Modling Its Strategic Impact. Journal of Managerial; Issues, Vo. IX, Number 4, Winter 1997 : 440 - 453)

34. Levitt, Joel, (2003). Preventive and Predictive Maintenance Industrial, Press Inc.200 Madison Avenue, New York

35. Mad Lazim, H., \& Ramayah, T. (2010). Maintenance strategy in Malaysian manufacturing companies: a total productive maintenance (TPM) approach. Business Strategy Series, 11(6), 387-396.

36. Mardianto Fariz Fadillah M, \& Nuri Wahyuningsih (2013). Multivariate Regression Model for Determining Regency and City Welfare Levels in East Java, Journal of Science and Art Pomits Vol. 2, No.1.

37. Melesse Workneh Wakjira \& Ajit Pal Singh, (2012). Total Productive Maintenance: A Case Study in Manufacturing Industry, Global Journal of Researches in Engineering, Industrial Engineering Volume 12 Issue 1 Version 1.0 February 2012.

38. Molamohamadi Zohreh \& Napsiah Ismail, (2013). Developing a New Scheme for Sustainable Manufacturing. International Journal of Materials, Mechanics and Manufacturing, Vol. 1, No. 1,

39. Nakajima, S. (1988). Introduction to total productive maintenance (TPM). Cambridge MA.

40. Nakajima, Seiichi (1998). Introduction to TPM Total Productive Maintenance, Productivity Press, Inc. Cambridge, Massachusetts Norwalk, Connecticut.

41. Nayak Disha M et al. (2013). Evaluation of OEE in A Continuous Process Industry on an Insulation Line in a Cable Manufacturing Unit, International Journal of Innovative Research in Science, Engineering and Technology, Vol. 2, Issue 5

42. Noor Juliansyah. (2015). Research Methodology, Prenadamedia Group, Jakarta

43. Oktaria Susanti (2011), Calculation and Value Analysis of Overall Equipment Effectiveness (OEE) In the Early Processing Process of Palm Oil (Case Study: PT X), published Thesis, Faculty of Engineering Industrial Engineering Program University of Indonesia, Depok.

44. Osada Takashi (1996), Work Attitude 5 S, Series Management Number 160, PT. Ikrar Mandiri abadi

45. Osada, T. (1989), 5S - Tezukuri no manajiment shuho (5S - Handmade Management Method), JIPM, Tokyo 
46. Osada, T. (1991), the 5S's: Five Keys to a Total Quality Environment, Asian Productivity Organisation, and Tokyo.

47. Parihar Soniya, et al., (2012). Calculation of OEE for an Assembly Process, International Journal of Research in Mechanical Engineering \& Technology IJRMET Vol. 2, Issue 2, 25-29

48. Patton, Joseph D, Jr, (1995). Preventive Maintenance, $2^{\text {nd }}$ Edition, the International Society for Measurement and Control

49. Puvanasvaran Perumal, Y.S. Teoh, C.C. Tay 2013, Consideration Of Demand Rate In Overall Equipment Effectiveness (OEE) On Equipment With Constant Process Time, Journal of Industrial Engineering and Management, JIEM, 2013 - 6(2): 507-524

50. Rajput Hemant Singh, Jayaswal Pratesh (2012), A Total Productive Maintenance (TPM) Approach To Improve Overall Equipment Efficiency, International Journal of Modern Engineering Research (IJMER) Vol.2, Issue.6, 4383-4386.

51. Rinawati Dyah Ika \& Dewi Nadia Cynthia (2014). Analysis of Total Productive Maintenance (TPM) Implementation Using Overall Equipment Effectiveness (OEE) And Six Big Losses At Cavitec Machine At PT. Essentra Surabaya, Pros erse SNATIF to -1, Faculty of Engineering Muria Kudus University, 21-26

52. Rosen Marc A. \& Hossam A. Kishawy (2012). Sustainable Manufacturing and Design: Concepts, Practices and Needs, Sustainability 2012, 4, 154-174; doi: 10.3390/su4020154, ISSN 2071-1050.

53. Sahu Shekhar, Lakhan Patidar \& Pradeep Kumar Soni (2015). 5S Transfusion to Overall Equipment Effectiveness (OEE) For Enhancing Manufacturing Productivity. International Research Journal of Engineering and Technology (IRJET), Volume: 02 Issue: 07 Oct-2015

54. Setiyawan Antonius Rudi. (2011). Analysis And Measurement Of Overall Equipment Effectiveness (OEE) Value As A Basic Improvement Of Manufacturing Process Line Plastic Injection Door Handle Car, Case Study PT. Sugity Creatives, Faculty of Engineering Industrial Engineering Program University of Indonesia, Depok.

55. Sharma Richa, Singh Jagtar (2015). Impact of Implementing Japanese 5S Practices on Total Productive Maintenance, International Journal of Current Engineering and Technology Vol.5, No.2, $818-825$

56. Shrivastava RL, Sanjeev Shrivastava \& S.K.Ganguly, (2014). Critical Success Factors for Cement Industry in India: A Case Study Analysis, International Journal of Core Engineering \& Management (IJCEM) Volume 1, Issue 7, 79-100

57. Singh Ranteshwar, et al. (2013), Total Productive Maintenance (TPM) Implementation in a MachineShop: A Case Study, Procedia Engineering 51, 592 - 599 Published by Elsevier Ltd. Available online at www.sciencedirect.com

58. Siriringo Hotniar \& Sudiyantoro, (2004). Total Productive Maintenance Analysis at PT. Wahana Eka Paramita GKD Group. Journal of Technology and Engineering Vol. 9, No. December 3, 2004.

59. Staniškis Jurgis K., \& Valdas Arbačiauskas (2009). Sustainability Performance Indicators for Industrial Enterprise Management, Environmental Research, Engineering and Management, No. 2(48), 42-50

60. Sudrajat, Ating, (2011). Practical Guidance on Industrial Machine Treatment Management, Bandung

61. Sugiyono, (2014). Statistics for Research, Alfabeta, Bandung

62. Sukwadi Roland, (2008). Difference Analysis Between Company Performance Factor Before and After Implementing Total Productive Maintenance (TPM) Strategy, (Case Study at PT Hartono Istana Technology, Product Home Division Appliances). University of Diponegoro Semarang,

63. Suriyanti, (2012). Impact of Integrated Quality Management Implementation on Customer Satisfaction and Organization Performance at Manufacturing Company in Makassar City, Dissertation, Post-Graduate Program University of Muslim Indonesia. 
64. Syarief Syafrizal (2010). Measurement of Overall Equipment Effectiveness (OEE) With Labview 8.5 As Maintenance Controller Published Thesis, Faculty of Engineering Industrial Engineering Program, University of Indoensia, Depok.

65. Tilkar Asim Kumar \& Nagaich Ravi (2013). A case study approach to productivity enhancement and calculation of Overall Equipment effectiveness, International Journal of Emerging Trends in Engineering and Development Issue 3, Vol.1, 632-640

66. Veleva Vesela, \& Ellenbecker Michael (2001). Indicators of sustainable production: framework and methodology, Journal of Cleaner Production 9, 519-549

67. Veleva Vesela, Jack Bailey \& Nicole Jurczyk (2001). Using Sustainable Production Indicators to Measure Progress in ISO 14001, EHS System and EPA Achievement Track, Journal Corporate Environmental Strategy, Vol. 8, No. 4, 326-338

68. Venkatesh, J. (2007). An introduction to total productive maintenance (TPM). The plant maintenance resource center, 3-20.

69. Vivek B Patel \& Hemant R Thakkar' (2014). Review Study on Improvement of Overall Equipment Effectiveness through Total Productive Maintenance, JETIR1407026 Journal of Emerging Technologies and Innovative Research, Dec 2014 (Volume 1 Issue 7)

70. Wudhikarn Ratapol (2013). A Framework for Integrating Overall Equipment Effectiveness with Analytic Network Process Method, International Journal of Innovation, Management and Technology, Vol. 4, No. 3, 351-355 